\title{
The role of the sharia supervisory board in the relationship of third-party fund and profits
}

\section{Fajriya Zakiyah, ${ }^{1}$ Prayogo Prasojoharto, ${ }^{2}$ Sepky Mardian ${ }^{3}$}

\author{
1,2,3STEI SEBI Depok, Indonesia \\ email: fajriyazaki@gmail.com
}

\begin{abstract}
Purpose - This study aims to find empirical evidence of the effect of growth of Third-Party Funds (TPF) on profit growth with the role of the Sharia Supervisory Board (SSB) as moderator in Islamic banks in Indonesia.

Method - This research is an associative research with a quantitative approach that used Panel Data Regression and Moderated Regression Analysis (MRA) as the data analysis methods. The research sample was 58 annual financial reports from 14 Islamic Commercial Banks in Indonesia.

Result - TPF had a significant positive effect on bank profit growth, but the role of the SSB could not moderate the growth of TPF on the profit growth of Islamic banks.

Implication - The implications of this research can strengthen the belief that Islamic banks need to improve the quality of their services and products to maintain the trust of customers and prospective customers to place their funds in Islamic banks.
\end{abstract}

Originality - The difference in this study when compared to other studies is the role of the Sharia Supervisory Board which is positioned as a moderating variable for the growth of Third-Party Funds on profit growth.

Keywords: third-party fund; profit growth; role of SSB; performance of Islamic banking 
Fajriya Zakiyah, Prayogo Prasojoharto, Sepky Mardian

\section{Introduction}

The development of Islamic banks in Indonesia is considered relatively good. This can be seen from the number of Islamic Commercial Banks (ICB) JIAFR | 202 which grew by 43 percent in the last decade. In 2019, the number of ICB in Indonesia was recorded at 14 banks from the beginning in 2009 which was only 6 banks (OJK, 2020). However, the development of Islamic banking must still be balanced by improving the quality of performance to maintain public confidence in this industry.

Islamic banks have special characteristics in which the implementation of their business activities is in line with the basic principles of Islamic economics. Therefore, public or stakeholder trust is a challenge for every bank that wants to grow and develop. The community or stakeholders will place funds in Islamic banks based on trust in Islamic banks which carry out their role for the welfare of the wider community with the basic principles of Islamic economics (Setiawan, 2009). One of the indicators that can be used by Islamic banks to gain public trust is good financial performance, namely the development of the bank's ability to collect and distribute funds which is marked by increased profits (Novitasari, 2015; Winarsih, 2017).

Profit growth can be caused by several factors; one of them is Third-Party Funds (TPF). TPF are vital because they are the main source of bank funds, the largest funds which come from the wider community (Masruroh \& Subagiyo, 2019). This is evidenced by data from the Financial Services Authority (OJK), that the increase of profit growth is accompanied by the increase in third party funds. For example, in 2018, the profit of Islamic Commercial Banks increased by $124 \%$ to IDR 3.8 trillion from the previous IDR 1.69 trillion. This was accompanied by the increase in TPF of $8 \%(\mathrm{OJK}$, 2020).

This is in line with research of Winarsih (2017) on BNI Syariah for the 2014-2016 period that TPF has a positive and significant effect on net income. The same result is also obtained by Marliana \& Fitri (2016). This is in contrast 
to a research conducted by Suryani \& Ika (2019) and Masruroh \& Subagiyo (2019) which concluded that TPF had no effect on profits.

On the other hand, one of the characteristics possessed by Islamic banks is the existence of a Sharia Supervisory Board (SSB). SSB plays a role in supervising the bank's financial activities and operations to ensure JIAFR | 203 compliance with sharia principles. However, the existence of SSB cannot guarantee that Islamic banks are free from violations of sharia principles. For example, in 2019, a fictitious credit case emerged in Indonesia involving several Islamic banks, namely Bank Panin Syariah and BJB Syariah. This fictitious credit case affected profit growth and TPF due to the distribution of financing to ineligible debtors (Septiadi, 2019). Credibility and trust in Islamic banks can also decrease due to the sharia violations that escape the supervision of SSB (Prabowo \& Jamal, 2017).

This is in line with research by Mukhibad \& Anisykurlillah (2020) which explains that the role of SSB in consulting and supervising the collection of funds and financing has an impact on bank profitability. However, a different result was stated by Zuliana \& Aliamin (2019) and Pramono \& Widiarto (2019) that SSB actually had a negative effect on the performance of Islamic banks in Indonesia. SSB is a unique part of the Good Corporate Governance (GCG) structure of Islamic banks (Alam et al., 2021; Garas \& Pierce, 2010). Its function in ensuring sharia compliance of products and services will provide social legitimacy to Islamic banks (Alam et al., 2021) . This legitimacy is reflected in the level of stakeholder trust in Islamic banks. Finally, this role will indirectly have an impact on the level of profitability of Islamic banks (Alam et al., 2021; Abdallah \& Bahloul, 2021; Garas \& Pierce, 2010).

This impact is also reflected in the function of SSB in providing knowledge to management related to sharia aspects, both in products and services. This understanding of sharia will be able to improve management performance in increasing operational profitability (Garas \& Pierce, 2010). In the perspective of agency theory, the profit generated by Islamic banks can be ascertained to be free from non-halal income. The role of SSB is expected to be able to become a filter for financing income originating from third party funds (Alam 
et al., 2021). This means that the intermediation function of Islamic banks in collecting third party funds and distributing them for profit can be maintained by the SSB in fulfilling its sharia principles. Therefore, based on the phenomenon and the research gap, this study re-examined the role of SSB on profit growth. Given the inconsistent results of previous studies, in this study a re-test is carried out with a change in methodology, that SSB is positioned as a moderating variable of TPF growth on profit growth.

\section{Literature Review}

\section{Agency Theory}

Agency theory developed by Jensen \& Meckling (1976) define an agency relationship, namely the owner (principal) delegates duties and obligations to management (agent). The agency relationship is governed by a contract that defines the duties and obligations of the agent, as well as the provision of remuneration to the assigned agent. When the principal delegates duties or authority to the agent, the risk that occurs is information asymmetry, the agent has better access to information than the principal. This agency problem is more intense in Islamic banks because profits and losses are shared between the bank and the Investment Account Holder (IAH).

The information asymmetry between management and other interested parties including investors, shareholders and the public can be reduced by conducting supervision (Obid \& Naysary, 2014). Supervision in Islamic banks, among others, can be carried out by SSB. SSB is an independent supervisor who ensures that banks run the sharia compliance, so that shareholders and investors can have access to more reliable and accurate information.

\section{Legitimacy Theory}

Burlea-schiopoiu \& Popa (2013) define legitimacy theory as a mechanism that supports organizations in meeting social norms so that organizations receive community recognition. This definition implies that the organization must play a role and be accepted by the community so that the organization can continue to operate (going concern). 
On the other hand, Islamic banks must be able to maintain their identity based on Islamic values to gain legitimacy (Ariyanto, 2014). This is because the level of public trust in the bank is related to the number of customers or Investment Account Holders (IAH). With increasing public trust, automatically more and more customers will entrust that their funds are managed by banks (Setyawan \& Adityawarman, 2017).

\section{Institutional Theory}

Scott in Hessels \& Terjesen (2010) defines institutional as an organizational social structure formed by cognitive, normative and regulatory culture. In other words, organizations are shaped by the pressures of the institutional environment. Meanwhile, Karbhari et al. (2020) believe that institutional theory can better explain the roles and responsibilities of various stakeholders in corporate governance than agency theory, stewardship theory and stakeholder theory.

In Islamic financial institutions, persistence in creating sharia-oriented banking must be accepted by all stakeholders who emphasize the cognitive component and normative culture, so that interested parties must comply with the rules based on the Qur'an and Sunnah. In this case, the role of the SSB in the internal structure of corporate governance can protect the image of Islamic banks.

\section{Third-Party Funds}

Third Party Funds (TPF) are the largest component in Islamic banks that are used to generate income or profits from the results of fund management (Haryati, 2018). TPF come from external sources, that is the community (Masruroh \& Subagiyo, 2019). In Islamic banks, the components of TPF include wadi'ah demand deposits, wadi'ah savings and mudharabah deposits. In this regard, the responsibility of Islamic banks is not only to shareholders, but also to customers (Setyawan \& Adityawarman, 2017). This fund ownership structure is an important factor that can affect the bank's 
performance. The level of trust in Islamic banks is one of the determinants of customers in choosing Islamic banks (Lahrech et al., 2014).

\section{Sharia Supervision}

JIAFR | 206

Sharia supervision is a mandatory thing that must be carried out by Islamic financial institutions to ensure that all bank's operations are in accordance with the sharia corridor. Garas \& Pierce (2010) highlight the importance of sharia supervision because it has economic power. This is because sharia supervision in creating sharia-compliant products can increase profitability. In this case, the Sharia Supervisory Board (SSB) represents the corporate governance mechanism in the form of compliance with sharia principles (Fitriana et al., 2019).

The existence of sharia supervisors is also regulated in Indonesian Law No. 21 of 2008 that Islamic banks are required to establish a SSB that is authorized to supervise and observe operational activities to ensure compliance with sharia principles. Thus, SSB has a very important role and position to improve the performance of Islamic banks through supervision of the operations and product development of Islamic banks in order to remain within the sharia corridor.

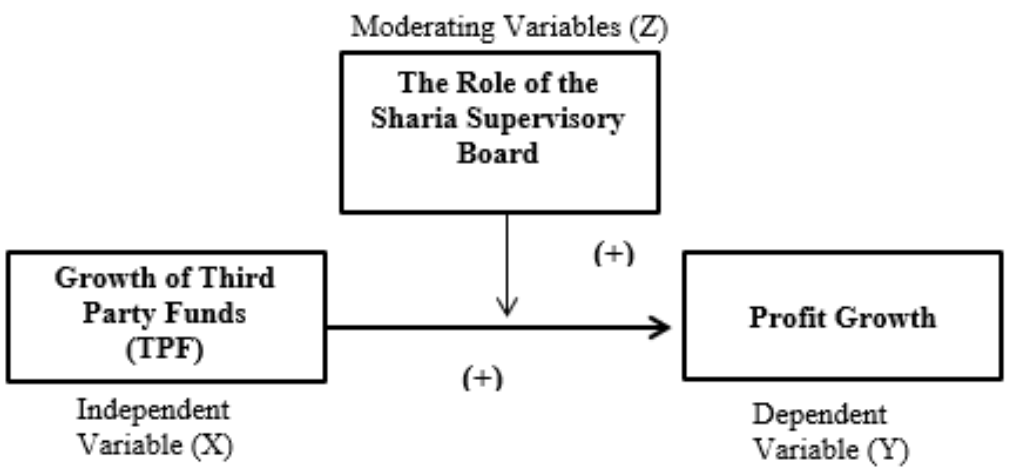

Figure 1. Theoretical Framework 
The role of the sharia supervisory boards in ...

\section{Profit Growth}

Sudarsono (2017) emphasizes that the ability of Islamic banks to generate profits is useful for banks and bank partners to assess the financial performance of banks. Profit is a sign for investing and an indication of the success of a business so that making a profit is the main goal of every institution or company (Masruroh \& Subagiyo, 2019).

According to Suryani \& Ika (2019), good profit growth is a sign for good Islamic bank performance which will automatically increase company value. Therefore, the ability to generate maximum profit in a bank is very important because basically IAH assesses the success of the bank based on the ability that can be seen from the performance of management in obtaining profits (Marliana \& Fitri, 2016).

\section{Hypothesis Development}

Every company has an interest in the legitimacy of stakeholders (Alam et al., 2021). For Islamic banks, the legitimacy of customers is crucial, because the largest source of funding for Islamic banks comes from customers. This legitimacy is obtained from the customer's trust in Islamic banks. This legitimacy and trust is reflected in the increase of third party funds. With an intermediary function, TPF will be a source of funding for financing that will provide income. If TPF increase or decrease, net profit growth will also increase or decrease. Therefore, the greater the growth of TPF, the greater the growth of net income so that there is a significant relationship between TPF and net income (Marliana \& Fitri, 2016; Nirwana \& Septiarini, 2015; Winarsih, 2017).

\section{$H_{1}$ : $\quad$ TPF growth has a positive effect on profit growth of Islamic commercial banks}

SSB can be considered as a party that can bridge the trade-off between the interests of the principal and the agent (Alam et al., 2021). The tendency of management to maximize interests by increasing income will be filtered by SSB by annulling income that is not in accordance with sharia principles 
(Garas \& Pierce, 2010). This means that the level of profitability of Islamic banks originating from non-Islamic income will be determined by the SSB, so that the tendency of increasing TPF which triggers an increase in profit also depends on the effectiveness of SSB supervision. Based on research by Mukhibad \& Anisykurlillah (2020), the Sharia Supervisory Board (SSB) has an indirect influence on Return on Assets (ROA) by strengthening bank fundraising. Therefore, this study examines the role of SSB as a moderator that will strengthen or weaken TPF to earnings. This is because the function of the SSB as an independent institution provides consultancy and supervision services on bank products and contracts.

$\mathrm{H}_{2}$ : The role of SSB in moderating the effect of TPF growth on the profit growth of Islamic commercial bank

\section{Research Methods}

The data used in this study are sourced from the audited Annual Report and the Good Corporate Governance (GCG) Report of Islamic commercial banks for the period 2015 to 2019. Panel Data Regression Method with unbalanced panel and Moderated Regression Analysis used to examine the effect and interaction between the moderating and independent variables.

The dependent variable of this study is the profit growth of Islamic commercial banks. Profit growth is the percentage increase in profit earned by the company in a certain period. This variable is measured by subtracting the profit of the current period $(\mathrm{t})$ with the profit of the previous period $(\mathrm{t}-1)$ then divided by the profit of the previous period (t-1) (Suryani \& Ika, 2019).

The independent variable in this study is the growth of TPF. TPF growth is the percentage increase in third party funds from a certain period (Sukmawati \& Purbawangsa, 2016). TPF is measured by adding up the total demand deposits, savings, and time deposits.

The moderating variable in this study is the role of SSB. The role of SSB is measured using the SSB-Index, namely the number of SSB in the bank, the frequency of SSB meetings, the expertise of the SSB in economics or finance, 
and the education level of the SSB. These four indicators will be calculated as follows: a) Number of SSB members in the bank: score 1 if the number of SSB is more than 2 and score 0 otherwise. b) Frequency of meetings by SSB: score 1 if more than 12 and score 0 otherwise. c) SSB expertise in economics: score 1 if the SSB member has experience in economics or finance. d) SSB education level: score 1 if SSB has taken doctoral education and score 0 otherwise.

The next step, the SSB-Index is calculated by adding up the value assigned to each indicator, then converting it to a percentage. Islamic banks that have a higher SSB-Index score indicate a stronger SSB quality. Meanwhile, a low score has a weaker SSB quality (Neifar et al., 2020).

\section{Results and Discussion}

Panel data regression is done by first determining the use of the most suitable model, Common Effect Model (CEM), Fix Effect Model (FEM) or Random Effect Model (REM). The selection of this model is important because the best selected model will be used to fulfill the requirements of data processing and the use of research assumptions. Tests on 3 panel data regression models consist of Chow test, Hausman test, and Lagrange Multiplier test. Furthermore, the best selected model will be used in the panel data regression equation in the study.

In the Chow test, the probability value is 0.542 . That is, if the probability value of $\mathrm{F}>$ critical limit, then $\mathrm{HO}$ is accepted or CEM is better than FEM. Furthermore, in the Hausman test, the probability value of chi squares is 0.262 , which means that if the probability value of chi squares is $>$ the significance level, then $\mathrm{HO}$ is accepted or REM is better than FEM. Lagrange Multiplier (LM) testing is the last stage of selecting the best model. Based on table 2, it can be seen that the Breusch-Pagan probability value is 0.497 , which means that if the p value > critical limit, then H0 is accepted or CEM is better than REM. Thus, in this study CEM was assessed as the best estimate of the panel data regression model.

If the regression model used is CEM, the classical assumption test that must be done is the heteroscedasticity test and multicollinearity test. 
Fajriya Zakiyah, Prayogo Prasojoharto, Sepky Mardian

However, the normality test is still carried out because it is one of the classical assumption requirements (Sakti, 2018).

Table 1. Model Regression Results

\begin{tabular}{cccccccccc}
\hline \multirow{2}{*}{ Variable } & \multicolumn{3}{c}{ Common Effect } & \multicolumn{3}{c}{ Fixed Effect } & \multicolumn{3}{c}{ Random Effect } \\
& Coef. & t-Stat & Prob. & Coef. & t-Stat & Prob. & Coef. & t-Stat & Prob. \\
\hline TPFG & 1,361 & 3,534 & 0,0008 & 1,487 & 3,693 & 0,0005 & 1,251 & 3,034 & 0,0037 \\
SSB & $-0,074$ & $-0,286$ & 0,776 & 0,019 & 0,072 & 0,943 & $-0,089$ & $-0,328$ & 0,744 \\
C & $-0,023$ & $-0,130$ & 0,897 & $-0,111$ & $-0,616$ & 0,541 & $-0,026$ & $-0,140$ & 0,889 \\
\hline
\end{tabular}

Source: Data processed with Eviews, 2021

Table 2. Model Selection Test Results

Dependent Variable: Profit Growth

\begin{tabular}{ccccccc}
\hline & \multicolumn{2}{c}{ Chow Test } & \multicolumn{2}{c}{ Hausman Test } & \multicolumn{2}{c}{ Lagrange Multiplier } \\
& \multicolumn{2}{c}{ F-stat } & P value & Chi- & P value & \multicolumn{2}{c}{ Breush- } & P value \\
& & & square & & Pagan & \\
Sig. level & 0,782 & 0,542 & 2,672 & 0,262 & 0,459 & 0,497 \\
& & 0,005 & & 0,005 & & 0,005 \\
\hline
\end{tabular}

Source: Data processed with Eviews, 2021

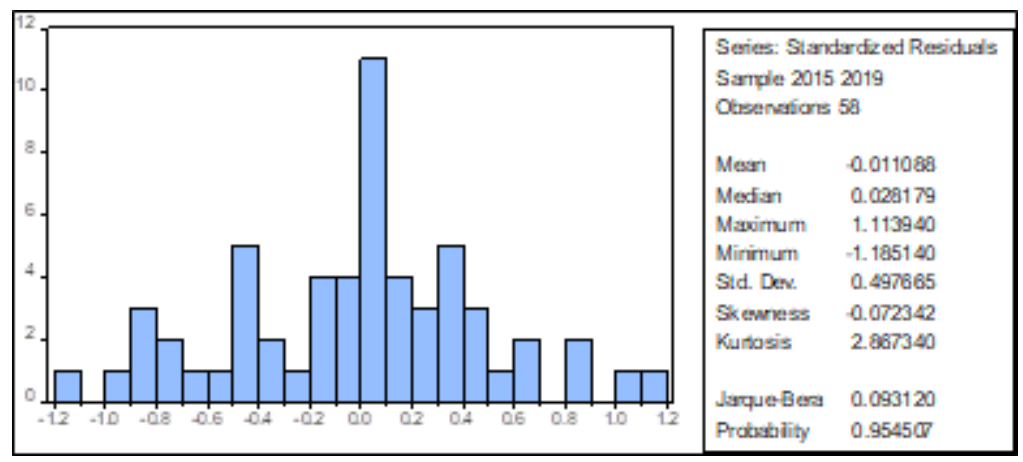

Figure 1. Normality Test 
The test results (figure 1) obtained the $p$ value of Jarque-Bera of 0.9545 . If $p$ value $>$ degree of error $=5 \%$, then the data is normally distributed. Meanwhile, the results of the multicollinearity test showed that none of the correlations between the independent variables had a value of more than 0.8 . That is, the regression model in this study does not have multicollinearity or there is no correlation between independent variables.

Furthermore, the heteroscedasticity test was carried out with the Park Test, which was regressing the residual square with the $\mathrm{x}$ variable. Based on table 3, the value of prob. The t-statistic on the growth variable of TPF is 0.3223 and the role of SSB is 0.6978 , which is greater than the degree of error $(\alpha=0.05)$. In addition, the F-statistical probability value of 0.609 shows the same thing, which is greater than $=0.05$ with an R-Squared of 0.0178 and Adj. R-Squared of 0.0179 which indicates a value smaller than 0.05 . So, it can be concluded that the regression model used in this study does not have heteroscedasticity so that testing on research data can continue.

This study uses the Common Effect Model (CEM) as the best model to analyze panel data regression. As a result, the Adjusted R-squared value obtained is 0.1755 or the dependent variable is influenced by the independent variable by 17.5 percent, while the remaining 82.5 percent of the dependent variable is influenced by other variants outside the research model. The probability value of t-statistics on the TPF Growth variable is 0.0008 or smaller than of 0.05 . Thus, the growth of TPF is proven to have a positive effect on profit growth.

Table 3. Heteroscedasticity Test

Dependent Variable: Profit Growth

\begin{tabular}{cccc}
\hline Variable & Koef. & t-Stat & Prob. \\
\hline TPFG & $-1,678247$ & $-0,998663$ & 0,3223 \\
SSB & $-0,445181$ & $-0,390279$ & 0,6978 \\
C & $-2,510747$ & $-3,210852$ & 0,0022 \\
F-Stat & 0,499675 & & \\
Prob. F-Stat & 0,609455 & & \\
R-Squared & 0,017846 & & \\
Adj. R-Squared & 0,017869 & & \\
\hline
\end{tabular}

Source: Data processed with Eviews, 2021 
Fajriya Zakiyah, Prayogo Prasojoharto, Sepky Mardian

Table 4. Regression Results with Common Effect Model

Dependent Variable: Profit Growth

*Significance level 0,05

JIAFR | 212

\begin{tabular}{cccc}
\hline Variable & Koef. & t-Stat & Prob. \\
\hline TPFG & 1,361203 & 3,533967 & 0,0008 \\
SSB & $-0,073543$ & $-0,286337$ & 0,7757 \\
C & $-0,022504$ & $-0,130133$ & 0,8969 \\
F-Stat & 7,066742 & & \\
Prob. F-Stat & 0,001856 & & \\
R-Squared & 0,204438 & & \\
Adj. R-Squared & 0,175508 & & \\
\hline
\end{tabular}

Source: Data processed with Eviews, 2021

Table 5. Test Results Moderated Regression Analysis

Dependent Variable: Profit Growth

\begin{tabular}{cccc}
\multicolumn{4}{c}{ *Significance level $\mathbf{0 , 0 5}$} \\
\hline Variable & Koef. & t-Stat & Prob. \\
\hline TPFG & 1,955269 & 2,862288 & 0,0060 \\
SSB & 0,051079 & $-0,176497$ & 0,8606 \\
TPFG*SSB & $-1,116527$ & $-1,011214$ & 0,3164 \\
C & $-0,098697$ & $-0,516992$ & 0,6073 \\
F-Stat & 5,279195 & & \\
Prob. F-Stat & 0,002887 & \\
R-Squared & 0,226777 & \\
Adj. R-Squared & 0,183821 & \\
\hline
\end{tabular}

Source: Data processed with Eviews, 2021

The results of this study support the legitimacy theory that customers or Investment Account Holders (IAH) can affect legitimacy. The higher the level of public trust in the bank, the greater the amount of IAH, indicated by an increase in TPF. The higher the TPF, the better the profit performance of Islamic banks. In addition, this study also strengthens the research of Winarsih (2017), Marliana \& Fitri (2016), and Nirwana \& Septiarini (2015) in which TPF growth has a positive relationship to profit growth. Thus, theoretically and empirically, it has been proven that TPF has a vital role in 
the performance of Islamic banks as seen from their profit growth. This also indicates that the bank has been able to optimize TPF in generating profits.

This interaction test or Moderated Regression Analysis (MRA) aims to test the interaction between the independent variable and the moderating variable. The probability value of the interaction between TPF growth and the role of SSB is 0.3164 and the $t$-statistic value is -1.11 or the probability value is greater than of 0.05 . Thus, the role of SSB is not proven to moderate the effect of TPF growth on profit growth.

The results of this study contradict the agency theory which states that the presence of SSB will reduce agency problems in Islamic banks. In addition, the results of this study also contradict the legitimacy and institutional theory that the role of SSB in the governance of Islamic banks is considered important as an independent internal monitor or control instrument so as to strengthen public trust to entrust their funds to Islamic banks.

This is probably because SSB is less effective in carrying out its supervisory function. Evidently, one of the SSB-Index indicators, the number of SSB meetings, is minimal or only to meet regulatory requirements. Sharia Supervisory Board carries out very little sharia supervision on Islamic banks that are placed. The sharia supervision carried out is not optimal because it does not check the format and contracts according to sharia principles, determine margins and so on (Prabowo \& Jamal, 2017). Thus, the existence of SSB is only a formality to fulfill regulations that require Islamic banks to have a SSB, but it is not accompanied by recognition from customers or the public (Pramono \& Widiarto, 2019). The ineffective role of SSB in supervision can result in a decrease in the credibility of Islamic banks so that public trust in Islamic banks can decrease (Prabowo \& Jamal, 2017).

\section{Conclusion}

The growth of TPF has been proven to have a significant positive effect on the profit growth of Islamic commercial banks. Thus, this research shows empirical evidence that banks can optimize TPF in generating profits. In addition, this study also strengthens the belief in the need for Islamic banks to 
maintain the trust of customers and prospective customers to place them in Islamic banks by improving the quality of their services and products. However, on the other hand, the role of SSB, as measured by the SSB-Index, is not proven to be able to moderate TPF growth towards profit growth of Islamic commercial banks. Therefore, in the next research, it is recommended to use other variables, such as financing growth, as a moderating variable. In addition, future research can research what factors have the most influence on TPF growth and profit growth.

\section{References}

Ariyanto, T. (2014). Analisis Pengaruh Pengungkapan Identitas Etis Islam terhadap Kinerja Keuangan Bank Syariah di Asia. Jurnal Akuntansi Dan Keuangan, 1(1), 98-110.

Burlea-schiopoiu, A., \& Popa, I. (2013). Legitimacy Theory. Encyclopedia of Corporate Social Responsibility, January. https://doi.org/10.1007/978-3-642-28036-8

Chandrarin. (2017). Metode Riset Akuntansi : Pendekatan Kuantitatif. Jakarta: Salemba Empat.

Fitriana, R., Yulianto, A., \& Solikhah, B. (2019). Are Characteristics of Sharia Supervisory Boards Able to Improve the Performance of Islamic Banking? Journal of Islamic Accounting and Finance Research, 1(1), 124. https://doi.org/10.21580/jiafr.2019.1.1.3753

Garas, S. N., \& Pierce, C. (2010). Shari'a Supervision of Islamic Financial Institutions. Journal of Financial Regulation and Compliance, 18(4), 386-407. https://doi.org/10.1108/13581981011093695

Haryati, N. (2018). Pengaruh Standar Akuntansi , Transparansi , dan Kinerja Bank terhadap Profitabilitas Bank Syariah di Indonesia dengan Profit Sharing sebagai Variabel Intervensi: Tinjauan Konseptual. Industrial Research Workshop and National Seminar, 9, 613-622. https://doi.org/https://doi.org/10.35313/irwns.v9i0.1105

Hessels, J., \& Terjesen, S. (2010). Resource dependency and institutional theory perspectives on direct and indirect export choices. Small Bus Econ, 34, 203-220. https://doi.org/10.1007/s11187-008-9156-4 
Jensen, M. C., \& Meckling, W. H. (1976). Theory of the Firm: Managerial Behavior, Agency Cost and Ownership Structure. Journal of Financial Economic 3, 3(4), 305-360.

Karbhari, Y., Alam, M. K., \& Rahman, M. M. (2020). Relevance of the application of institutional theory in Shariah governance of Islamic banks. Emerald. https://doi.org/10.1108/PRR-05-2020-0015

Lahrech, N., Lahrech, A., \& Boulaksil, Y. (2014). Transparency and performance in Islamic banking Implications on profit distribution. International Journal of Islamic and Middle Eatern Finance and Management, 7(1). https://doi.org/10.1108/IMEFM-06-2012-0047

Marliana, C., \& Fitri, M. (2016). Pengaruh Biaya Operasional, Dana Pihak Ketiga dan Non- Performing Finance terhadap Pertumbuhan Laba pada Perbankan Syariah di Indonesia. Jurnal Ilmiah Mahasiswa Ekonomi Akuntansi (JIMEKA), 1(1), 247-257.

Masruroh, F. D., \& Subagiyo, R. (2019). Pengaruh Dana Pihak Ketiga dan Jumlah Pembiayaan terhadap Laba Bank Syariah Mandiri. Al-Masharif: Jurnal Ilmu Ekonomi Dan Keislaman, 7(1), 63-81. https://doi.org/10.24952/masharif.v7i1.1620

Muhammadinah. (2020). Pengaruh Pertumbuhan Dana Pihak Ketiga terhadap Pertumbuhan Laba dengan Pertumbuhan Pembiayaan sebagai Variabel Moderating pada Bank Syariah di Indonesia. TECHNOBIZ, 3(2), 1-6.

Mukhibad, H., \& Anisykurlillah, I. (2020). Evaluation Study: Does The Sharia Supervisory Board Have A Direct Effect on Profitability? 11(1), 55-69. https://doi.org/10.18326/muqtasid.v11i1.55-69

Neifar, S., Salhi, B., \& Jarboui, A. (2020). The Moderating Role of Shariah Supervisory Board on the Relationship Between Board Effectiveness, Operational Risk Transparency and Bank Performance. International Journal of Ethics and Systems, 36(3), 325-349. https://doi.org/10.1108/IJOES-09-2019-0155

Nirwana, L. P., \& Septiarini, D. F. (2015). Pengaruh Pertumbuhan Dana Pihak Ketiga terhadap Laba Perbankan Syariah di Indonesia. JESTT, 2(8), 642-657. https://doi.org/10.20473/vol2iss20158pp642-657

Novitasari, D. R. (2015). Pengaruh Tingkat Kesehatan Bank dengan Metode CAMELS terhadap Pertumbuhan Laba pada Bank Umum Syariah Periode 2011-2014. Jurnal Akuntansi UNESA, 1-20. 
Fajriya Zakiyah, Prayogo Prasojoharto, Sepky Mardian

Obid, S. N. S., \& Naysary, B. (2014). Toward a Comprehensive Theoritical Framework for Shariah Governance in Islamic Financial Institutions. Journal of Financial Services Marketing, 19(4), 304-318. https://doi.org/10.1057/fsm.2014.26

JIAFR | 216 OJK. (2020). Statistik Perbankan Syariah Juni 2020.

Prabowo, B. A., \& Jamal, J. Bin. (2017). Peranan Dewan Pengawas Syariah terhadap Praktik Kepatuhan Syariah dalam Perbankan Syariah di Indonesia. JHIus Quia Iustum, 24(1), 113-129. https://doi.org/https://doi.org/10.20885/iustum.vol24.iss1.art6

Pramono, N. H., \& Widiarto, A. (2019). Kinerja Keuangan Bank Syariah di Indonesia. ACCOUNTHINK: Journal of Accounting and Finance, 4(01), 685-697. https://doi.org/10.35706/acc.v4i1.1821

Sakti, I. (2018). Analisis Regresi Data Panel Menggunakan Eviews. Modul Eviews 9, 1-25.

Septiadi, A. (2019). Kasus Kredit Fiktif, ini penjelasan Panin Syariah soal suntikan modal induk. Keuangan.Kontan.Co.Id. https://keuangan.kontan.co.id/news/kasus-kredit-fiktif-inipenjelasan-panin-syariah-soal-suntikan-modal-induk

Setiawan, A. B. (2009). Kesehatan Finansial dan Kinerja Sosial Bank Umum Syariah di Indonesia. Universitas Paramadina, 1-55.

Setyawan, C. D., \& Adityawarman. (2017). Pengaruh Dewan Komisaris dan Investment Account Holders terhadap Kinerja Bank Syariah di Indonesia. Diponegoro Journal of Accounting, 6, 1-11.

Sudarsono, H. (2017). Analisis Pengaruh Kinerja Keuangan terhadap Profitabilitas Bank Syariah di Indonesia. Economica: Jurnal Ekonomi Islam, 8 ,

175-203. https://doi.org/10.21580/economica.2017.8.2.1702

Sukma, Y. L. (2013). Pengaruh Dana Pihak Ketiga, Kecukupan Modal dan Risiko Kredit terhadap Profitabilitas. Jurnal Akuntansi, 1(2). ejournal.unp.ac.id

Sukmawati, N. M. E., \& Purbawangsa, I. B. A. (2016). Pengaruh Pertumbuhan Dana Pihak Ketiga, Pertumbuhan Kredit, Risiko Kredit, Likuiditas dan Kondisi Ekonomi terhadap Profitabilitas. E-Jurnal Manajemen Unud, 5(9), 5398-5432. https://ojs.unud.ac.id/index.php/Manajemen/article/view/19539 
Suryani, Y., \& Ika, D. (2019). Faktor-Faktor Yang Mempengaruhi Pertumbuhan Laba Bank Umum Syariah di Indonesia. Jurnal Akuntansi Dan Bisnis, 5(2), 115-128. https://doi.org/10.31289/jab.v5i2.2642

Winarsih, W. (2017). Pembiayaan Dana Pihak Ketiga pada Pertumbuhan Laba Bersih Bank BNI Syariah. Jurnal Ekonomi Syariah Dan Filantropi Islam, 1(2), 224-237. https://doi.org/10.22236/alurban

Zuliana, R, \& Aliamin. (2019). Pengaruh Dewan Pengawas Syariah, Intellectual Capital, dan Corporate Social Responsibility terhadap Kinerja Bank Syariah di Indonesia. Jurnal Ilmiah Mahasiswa Ekonomi Akuntansi (IIMEKA), $4(4)$, https://doi.org/10.24815/jimeka.v4i4.15335 677-693. 
JIAFR | 218 